\title{
The Roles of Technology Literacy and Technology Integration to Improve Students' Teaching Competencies
}

\author{
Arif Santoso and Sari Lestari
}

Economics Education Department, Universitas Negeri Semarang, Semarang, Indonesia

\section{Abstract}

Students majoring in accounting education should be equipped not only with the contents of subject matters but also the pedagogy skills. Previous studies show that there is still a significant gap between student's teaching competencies prepared by the university and the teaching competencies required by the schools. Current development in technology changes the way students learn and teachers teach as students and teachers can easily acquire new knowledge and skills through the use of technology. The study aims at identifying the influence of technology literacy and technology integration on the students' teaching competencies. It employs quantitative

Corresponding Author:

Arif Santoso

arfsan12@gmail.com

Received: 29 January 2019 Accepted: 27 February 2019 Published: 24 March 2019

Publishing services provided by Knowledge E

(c) Arif Santoso and Sari Lestari. This article is distributed under the terms of the Creative Commons Attribution License, which permits unrestricted use and redistribution provided that the original author and source are credited.

Selection and Peer-review under the responsibility of the 3rd ICEEBA Conference Committee. approach and collects data from students majoring in accounting education-both regular and international classes. By using random sampling technique and Likert-type questionnaire with five scales, the study collected 86 data from respondents. The results of regression analysis show that that technology literacy and technology integration have a significant influence on students' teaching competencies. The determination coefficient reaches the percentage of $32.8 \%$, meaning that the competency of student to teach is determined $32 \%$ by both the independent variables. The faculty should provide more facilitation to students majoring in accounting education to ensure that they can improve their technology literacy. Faculty also should provide more technology facilities to the students and lecturers to enable them to catch up with technology advancements. Future research should provide more comprehensive model by including other variables having potentials to contribute to students' teaching competencies.

Keywords: technology literacy, teaching competency, technology integration

\section{Introduction}

The world is entering the industrial revolution 4.0, a concept introduced by Prof. Klaus Schwab (2017) in his book entitled The Fourth Industrial Revolution. According to Schwab, the industrial revolution 4.0 is an era that is disruptive and has fundamentally changed human life and work. This era is marked by the rapid development of information technology as the main base that has a big influence in every line of human 
of new technologies that integrate the physical, digital and biological worlds affect all disciplines including in the field of education (Schwab, 2015).

Rapid technological advances need to be balanced and mastered by every prospective teacher. Currently information is easily obtained from anywhere through internet facilities. The existence of technology is very close to students. Most students prefer to find references from the internet rather than reading books for various reasons ranging from efficiency, more references, and others. Student knowledge is not limited to the learning process in the classroom and library but from various materials and information on the internet.

According to Komalasari (2013) learning is a learning system or process that is planned, implemented and evaluated systematically so that learners can achieve learning objectives effectively and efficiently. While teaching competence is a science and insight on how to provide learning to students. Every educator has its own way of conveying learning material to students which is certainly adjusted to the characteristics of students and the abilities possessed by the educator itself.

Some factors that influence teaching competency are technology literacy. Technology literacy is the ability of a person to work independently and collaborate with others effectively, responsibly and precisely by using technological instruments to obtain, manage, then integrate, evaluate, create and communicate information. Millennials must have data literacy, technology literacy and human literacy to be ready to face the challenges of the industrial era 4.0 (Misbah Fikrianto, 2018). Technology literacy ability enables people to utilize technology to increase their capacity and competence, namely teaching knowledge. This is in line with the results of research conducted by Friska Tianada (2015) which states that technological literacy has a significant influence on teaching competencies. Therefore, the hypothesis that is formed is: $\mathbf{H} \mathbf{1}$ Technology literacy significantly

\section{influenced teaching competency}

In the Education 4.0 era like today, the learning process is not only done conventionally but starts to shift to a technology-based learning process. Each campus tries to integrate technology in each faculty according to their individual needs. The existence of integrated technology in this faculty will greatly facilitate the learning process and increase student competence. E-learning, e-administration, computer laboratories, and websites are some examples of the integration of technology on campus. This is in line with the results of Muksin Wijaya's (2012) study where technology integration significantly influences teaching ability. The hypothesis that is formed is: H2 Technology

integration significantly influenced teaching competency 
In addition, this study also describes how the two variables, technology literacy and technology integration, affect teaching competency in students. Therefore the hypothesis that is formed is: H3 Technology literacy and technology integration simultaneously influenced teaching competency

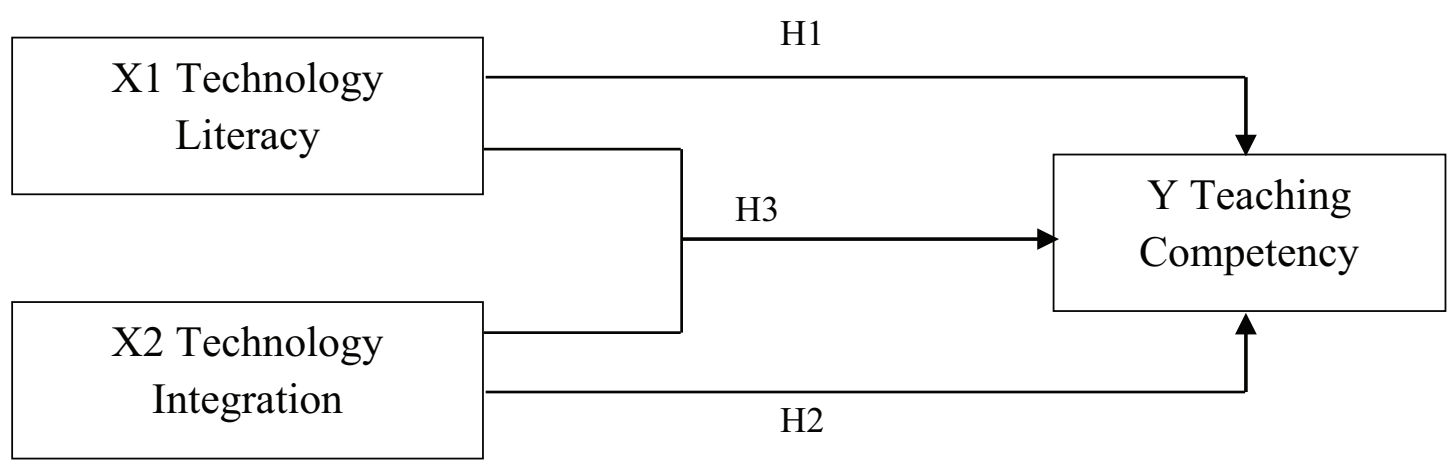

Figure 1: Theoretical framework of the study.

\section{Literature Review}

\subsection{Teaching competency}

The term competency comes from English, namely "competence means fitness or ability" which means ability or ability. According to the Ministry of National Education (2003) "Competence is knowledge, skills and basic values that are reflected in the habits of thinking and acting or the specifications of the knowledge, skills and attitudes that must be possessed by a person and their application." Teaching competence alone is the knowledge, skills, and abilities of an education in delivering learning material to its students. This competence must be owned by all educators, because this competence is a basic competency and determines whether or not a learning process is successful. Anies Baswedan (2018) said that improving teacher competency is the main focus and a necessity. He also added that the teacher is currently facing 21 st century students. Where 21st century students are students who are close to the development of Science and Technology so that it needs to be balanced by a teacher. Improved teaching competencies are influenced by various things including the development of Technology and Information. 


\subsection{Technology literacy}

Searching for the term Technology literacy is always related to Information and Communication Technology (ICT). Markauskaite, L. (2006) suggests that technological literacy is part of ICT literacy that falls into the category of inter-literacy perspectives including the ability to use ICT as an integral part of basic literacy. Basic literacy is divided into two aspects. First, ICT knowledge perspective fundamentals include knowledge of concepts and understanding of theoretical principles about computers, information systems, digital information, algorithmic thinking and programming, technological limitations, and social impacts. Second, the Basic ICT skills perspective includes understanding and having the ability to use ICT equipment, such as word processing and numbers.

Furthermore, Maryl and Technology Education State Curriculum suggests that technology literacy is the ability to use, understand, regulate and assess an innovation that involves processes and knowledge to solve problems and expand one's abilities. According to the National Academy of Engineering and the National Research Council of The National Academics, literacy technology is an understanding of technology at a level that enables effective use in modern technology which consists of three main components, namely knowledge, ability and critical thinking, and decision-making. According to Rose (2007: 43 ) the term technology literacy can be interpreted as: Understanding of man-made works. The relationship between science, environment, and technology The ability to use technology, especially in learning and teaching science and the ability to work. Ability to evaluate and make decisions.

Based on the above definition, technology literacy can be interpreted as an ability that consists of aspects of science, critical thinking skills, and decision-making in an effort to effectively utilize technology/innovation of human works, especially in the world of education.

\subsection{Technology integration}

When once technology tools are available, faculty will necessarily and integrate them into their classroom instruction to enhance student learning. Consequently, then, the challenge for researchers is quantify the use of technology to support student learning (Oppenheimer, 2003; Roblyer \& Knezek, 2003; Strudler, 2003). While various studies have explored the factors that enhance integration of technology into instruction as well as the barriers to effective technology integration, few studies are available on students perceptions of computer technology use and the impact of these perceptions on them 
learning. In addition, while the public interest in the use and integration of computer technology in education is growing, research in this area is still in its infancy, especially that which focuses on classroom instruction. Besides, rapid improvement in educational technologies exceeds the current knowledge of effective computer technology use in education (Allen, 2001) and the implies need for a study such as this. The pressure to reform education through technology integration (Becker, 2001) and the emphasis on developing information literacy skills for students (Rockman, 2004) implies the need for an understanding of current technology integration practices to support student learning. Therefore, the purpose of this study is to explain the influence of technology literacy and faculty integration of technology on knowledge of teaching for students.

\subsection{Methodology}

This research was conducted at the Faculty of Economics, Semarang State University. This research is quantitative research. Where in this study there are three variables, namely technology literacy, technology integration, and teaching competency. The population of this study were students majoring in accounting education in the year 2016 totaling 110 students. Sampling was done by random sampling with 86 students as respondents. Respondents were taken from regular and international class students. The selection of respondents is done by random sampling. According to Sugiyono (2017) simple random sampling is the taking of a member of a sample of a population that is done randomly without regard strata that exist in that population. The main requirement that must be met to be able to use random sampling is that there must be a clear sampling frame. This requirement has been fulfilled therefore in this study using random sampling.

This study uses primary data, where data is taken by distributing questionnaires. Then the questionnaire was assessed by Likert items (5: strongly agree, 4: agree, 3: neutral, 2: disagree, and 1: strongly disagree). Question items in the questionnaire adapted from previous research. This is done to minimize the occurrence of errors in research. After the questionnaire was filled in, data was collected and analyzed using descriptive statistics and multiple linear regression tests using the Statistical Package for Social Sciences (SPSS) version 21.0 application. Before the data is analyzed, validity and reliability tests are carried out.

\section{Results and Discussion}




\subsection{Reliability test}

According to Sugiono (2005) reliability test is a series of measurements or a series of measuring instruments that have consistency if the measurements made with the measuring instrument are carried out repeatedly. Reliability test is used to measure the level of consistency of a test to assess the extent to which a test can be trusted to produce a consistent score, relatively unchanged despite being tested in different situations. A study is said to be reliable if it has a Cronbach alpha $>0.70$ (Nunnally, 1994).

TABLE 1: Reliability Analysis.

\begin{tabular}{|l|c|c|c|}
\hline Variable & $\begin{array}{c}\text { Number of } \\
\text { Items }\end{array}$ & $\begin{array}{c}\text { No. of the } \\
\text { Delete } \\
\text { Items }\end{array}$ & $\begin{array}{c}\text { Cronbach's } \\
\text { Alpha }\end{array}$ \\
\hline Technology Literacy & 15 & 2 & 0.847 \\
\hline Technology Integration & 15 & 0 & 0.878 \\
\hline Teaching Competency & 12 & 0 & 0.889 \\
\hline Source: Processed Data (2018) & & &
\end{tabular}

The table above shows that technology literacy (X1) has a Cronbach's Alpha by 0847 which means high reliability because it has a value between $0.70-0.90$, technology integration (X2) has a Cronbach's Alpha by 0.878 which means high reliability, as well as teaching competency has a high reliability with Cronbach's Alpha of 0.889 .

\subsection{Validity test}

According to Sugiyono (2017), the validity test is a test that shows the degree of accuracy between the data that actually occurs on objects with data collected by researchers. Testing is done by comparing score items with total scores using correlation analysis. The study is said to be valid if the significance is $<0.05$ and if it has $r$ count $>0.2096$ in this study.

TABLE 2: Validity Test.

\begin{tabular}{lcc} 
Items & $\begin{array}{c}\text { Pearson } \\
\text { Correlation }\end{array}$ & Sig. (2-tailed) \\
$\begin{array}{l}\text { Technology Literacy } \\
\text { I am sure that I have the ability to do activities related to } \\
\text { technology }\end{array}$ & 0.497 & 0.000 \\
\hline I often do activities related to the use of technology & 0.645 & 0.000 \\
$\begin{array}{l}\text { E-learning is effective to be applied in lectures } \\
\text { I rarely update about the development of science and } \\
\text { technology }\end{array}$ & 0.485 & 0.000 \\
\hline
\end{tabular}




\begin{tabular}{|c|c|c|}
\hline Items & $\begin{array}{l}\text { Pearson } \\
\text { Correlation }\end{array}$ & Sig. (2-tailed) \\
\hline I often use the internet in the world of lectures & 0.570 & 0.000 \\
\hline $\begin{array}{l}\text { I take advantage of technological developments to support } \\
\text { my presentation. }\end{array}$ & 0.765 & 0.000 \\
\hline I use learning media at each presentation & 0.555 & 0.000 \\
\hline I immediately opened the internet when I didn't know & 0.644 & 0.000 \\
\hline Technology is very beneficial for educators & 0.653 & 0.000 \\
\hline $\begin{array}{l}\text { Learning strategies can be combined with technological } \\
\text { developments }\end{array}$ & 0.668 & 0.000 \\
\hline By following the development of technology, I can teach well & 0.600 & 0.000 \\
\hline $\begin{array}{l}\text { The use of IT in learning activities increases the enthusiasm } \\
\text { of students }\end{array}$ & 0.663 & 0.000 \\
\hline I am used to using computers, cellphones and the internet & 0.782 & 0.000 \\
\hline \multicolumn{3}{|l|}{ Technology Integration } \\
\hline Technology integration in my faculty is good & 0.591 & 0.000 \\
\hline $\begin{array}{l}\text { Sikadu and Elena are useful and effective in lecturing } \\
\text { activities }\end{array}$ & 0.726 & 0.000 \\
\hline The use of e-mail makes it easy for students & 0.561 & 0.000 \\
\hline My faculty has adequate learning facilities & 0.646 & 0.000 \\
\hline $\begin{array}{l}\text { Faculties and infrastructure of faculties facilitate learning } \\
\text { activities }\end{array}$ & 0.572 & 0.000 \\
\hline The projector helps the learning process & 0.630 & 0.000 \\
\hline $\begin{array}{l}\text { Technology devices are integrated with the accounting } \\
\text { education study program curriculum }\end{array}$ & 0.622 & 0.000 \\
\hline Utilization of IT facilitates learning activities & 0.668 & 0.000 \\
\hline $\begin{array}{l}\text { The use of facilities and infrastructure in accordance with the } \\
\text { curriculum }\end{array}$ & 0.682 & 0.000 \\
\hline Computer labs are very adequate & 0.641 & 0.000 \\
\hline My Unnes increases student knowledge & 0.565 & 0.000 \\
\hline $\begin{array}{l}\text { Service Letter Information System (SIRADI) makes it easy to } \\
\text { create letters }\end{array}$ & 0.707 & 0.000 \\
\hline Lecturers give me the benefit of IT development & 0.572 & 0.000 \\
\hline $\begin{array}{l}\text { Accounting education students are accustomed to using } \\
\text { technology on campus }\end{array}$ & 0.683 & 0.000 \\
\hline $\begin{array}{l}\text { All students are able to operate IT facilities and infrastructure } \\
\text { on campus }\end{array}$ & 0.332 & 0.002 \\
\hline \multicolumn{3}{|l|}{ Teaching Competency } \\
\hline $\begin{array}{l}\text { I think teaching knowledge can be improved by the } \\
\text { presence of technology literacy and technology integration }\end{array}$ & 0.751 & 0.000 \\
\hline I feel my teaching ability has increased since I used IT & 0.611 & 0.000 \\
\hline My value increases when I use IT & 0.636 & 0.000 \\
\hline $\begin{array}{l}\text { Technology and technology literacy that is integrated in the } \\
\text { faculty makes it easier for me to deliver material }\end{array}$ & 0.735 & 0.000 \\
\hline $\begin{array}{l}\text { Integrated technology and technology literacy in the faculty } \\
\text { is able to improve student skills }\end{array}$ & 0.716 & 0.000 \\
\hline
\end{tabular}




\begin{tabular}{|c|c|c|}
\hline Items & $\begin{array}{l}\text { Pearson } \\
\text { Correlation }\end{array}$ & Sig. (2-tailed) \\
\hline I often use IT in daily activities & 0.566 & 0.000 \\
\hline $\begin{array}{l}\text { Technology and technology literacy that is integrated in the } \\
\text { faculty makes it easier for me to master competence as a } \\
\text { prospective educator }\end{array}$ & 0.749 & 0.000 \\
\hline $\begin{array}{l}\text { My teaching ability increased when I mastered technology } \\
\text { literacy and the integration of technology in the faculty }\end{array}$ & 0.774 & 0.000 \\
\hline $\begin{array}{l}\text { Student competency increases with technology literacy and } \\
\text { technology integration in the faculty }\end{array}$ & 0.614 & 0.000 \\
\hline $\begin{array}{l}\text { Technology and technology literacy that is integrated in the } \\
\text { faculty makes it easy to assess students }\end{array}$ & 0.703 & 0.000 \\
\hline $\begin{array}{l}\text { Technology and technology literacy that is integrated in the } \\
\text { faculty makes it easy to make variations }\end{array}$ & 0.563 & 0.000 \\
\hline $\begin{array}{l}\text { Integrated technology and technology literacy in the faculty } \\
\text { increases the enthusiasm of students }\end{array}$ & 0.691 & 0.000 \\
\hline
\end{tabular}

Based on the table above it can be concluded that all data is valid, because all data have a significant value of $<0.05$ and $r$ count is more compared to $r$ table.

\subsection{Data analysis}

\subsubsection{Coefficient of determination}

TABLE 3: Coefficient of determination.

\begin{tabular}{|c|c|c|c|c|}
\hline \multicolumn{5}{|c|}{ Model Summary } \\
\hline Model & $\mathbf{R}$ & R Square & $\begin{array}{l}\text { Adjusted R } \\
\text { Square }\end{array}$ & $\begin{array}{l}\text { Std. Error of the } \\
\text { Estimate }\end{array}$ \\
\hline 1 &, $587^{a}$ & .344 & .328 & 2.881 \\
\hline \multicolumn{5}{|c|}{ a. Predictors: (Constant), X2, X1 } \\
\hline \multicolumn{5}{|c|}{ Source: Processed Data (2018) } \\
\hline
\end{tabular}

Based on the data above, it is known that the adjusted $\mathrm{R}$ square is 0.328 , which means that the variation of $32.8 \%$ teaching competency can be explained by the second variation of variable technology literacy and technology integration. While 67.2\% (100\% $-32.8 \%$ ) is explained or influenced by other variables not examined in this study. This shows a very large role shown by technological literacy and technology integration in improving teaching competencies in students.

\subsubsection{Partial determination coefficient}

Based on Table 4, it can be seen that all variables, namely technology literacy (X1) and technology integration $(X 2)$ influence teaching competency in students. Partially 
TABLE 4: Partial Determination Coefficient.

\begin{tabular}{|c|c|c|c|c|c|c|}
\hline \multicolumn{7}{|c|}{ Coefficients $^{a}$} \\
\hline \multicolumn{2}{|c|}{ Model } & \multicolumn{2}{|c|}{ Unstandardized Coefficients } & \multirow{2}{*}{$\begin{array}{c}\text { Standardized } \\
\text { Coefficients } \\
\text { Beta }\end{array}$} & \multirow[t]{2}{*}{$\mathbf{t}$} & \multirow[t]{2}{*}{ Sig. } \\
\hline & & B & Std. Error & & & \\
\hline \multirow[t]{3}{*}{1} & (Constant) & 18.375 & 4.551 & & 4.038 & .000 \\
\hline & $\mathrm{X} 1$ & .250 & .090 & .303 & 2.769 & .007 \\
\hline & $\times 2$ & .275 & .084 & .357 & 3.263 & .002 \\
\hline \multicolumn{7}{|c|}{ a. Dependent Variable: $Y$} \\
\hline \multicolumn{7}{|c|}{ Source: Processed Data (2018) } \\
\hline
\end{tabular}

the effect of technological literacy $(X 1)$ on teaching competency $(Y)$ is $9.18 \%$ and partial technology integration ( $\mathrm{X} 2$ ) on teaching competency $(\mathrm{Y})$ is $12.75 \%$. This shows that technology literacy and technology integration have an important role to improve teaching competence in students majoring in Accounting Education.

\subsubsection{Simultaneous significance test (F-Test)}

TABLE 5: F-Test results.

\begin{tabular}{|c|c|c|c|c|c|c|}
\hline \multicolumn{7}{|c|}{ ANOVA $^{a}$} \\
\hline \multicolumn{2}{|c|}{ Model } & Sum of Squares & df & Mean Square & $\mathbf{F}$ & Sig. \\
\hline \multirow[t]{3}{*}{1} & Regression & 361.753 & 2 & 180.876 & 21.785 & $0.000^{b}$ \\
\hline & Residual & 689.131 & 83 & 8.303 & & \\
\hline & Total & 1050.884 & 85 & & & \\
\hline \multicolumn{7}{|c|}{ Note: a. Dependent Variable: Y; b. Predictors: (Constant), X2, X1. } \\
\hline \multicolumn{7}{|c|}{ Source: Processed Data (2018) } \\
\hline
\end{tabular}

From the $F$ test, the $F$ value is 21.785 with a probability of 0.000 . Because the probability is far less than the regression model so it can be said that technological literacy and technology integration together influence teaching competency. This shows that the higher the knowledge of technological literacy and the integration of technology in the faculty will further improve the teaching competence of students.

\subsubsection{Individual parameter significance test (T-Test)}

Based on Table 6, of the two independent variables that entered the regression model showed that the two variables were significant to teaching competency. This can be seen from the probability significance value, where technology literacy has a value of 
TABLE 6: $T$-test results.

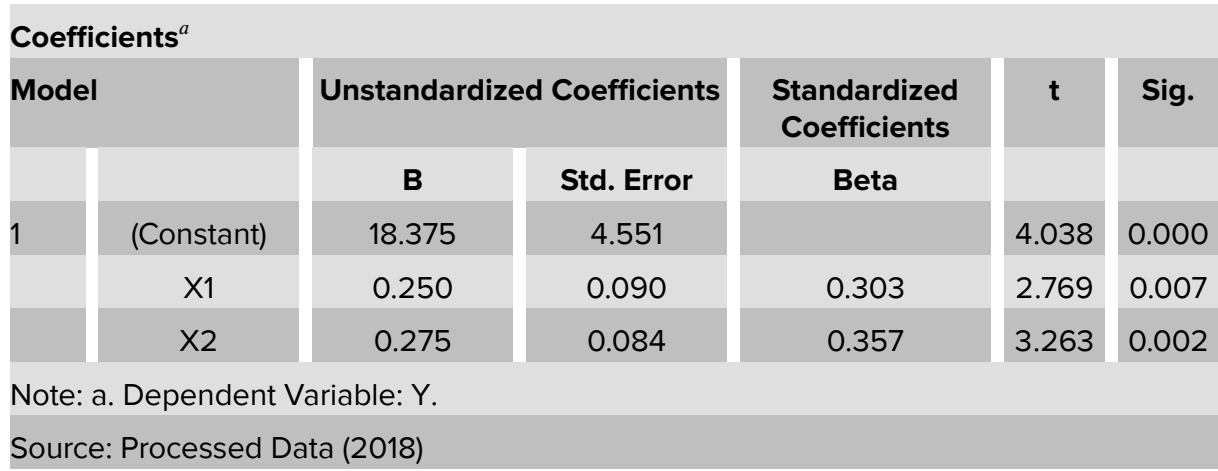

0.007 and technology integration has a value of.002. So the mathematical equation that is formed is as follows: $Y=18.375+0.250 \times 1+0.275 \times 2+e$

Based on the research results above, it can be stated that:

H1 Technology literacy significantly influenced teaching competency was accepted.

H2 Technology integration significantly influenced teaching competency was accepted.

H3 Technology literacy and technology integration simultaneously influenced teaching competency was accepted.

The results of the study show that technology literacy and technology integration influences teaching competency in students, especially accounting education students. This is understandable because students use technological advancements to find various sources of learning materials to add their insights and utilize the advancement of technology to be applied in daily learning activities such as to make presentations and make learning media easier. Students are allowed to use laptops or cellphones to search for various references to make it easier to understand a particular material. Besides that, students stated that the existence of integrated technology in faculties and student learning activities made it easier for students to receive materials and undergo daily lecture activities and train students to utilize existing technology to facilitate them in delivering material and attract students to stay focused on participate in learning activities. Students realize that the direction of education that has entered Education 4.0 requires them to be able to understand, follow, and apply technology into learning activities and daily activities. The effect of technology integration is greater than technology literacy. This is understandable because rationally the technology that has been integrated on campus will be used by lecturers and students in conducting daily learning so that the impact on improving teaching competency is higher. While the high level of technology literacy in students is influenced by the students' personalities so 
that technology literacy between students is different. If students have more interest in technology, the student will find out more about technology so that technology literacy will increase. Literacy technology and technology integration will have a very large role if the two variables are juxtaposed. This is understandable because the integration of technology in the faculty will be directly utilized and indirectly able to increase technology literacy in students. Therefore, the influence on improving teaching competence will also be greater.

Thus, students need to be emphasized to have insight into technological literacy so that their teaching competencies increase. Students need to be introduced and familiarized to always be close to technology as an effort to improve technology literacy and faculties must provide more facilitation to students majoring in accounting education to ensure they can improve their technological literacy. The faculty must also provide more technology facilities to students and lecturers to enable them to pursue technological advancements.

\section{Conclusion}

Based on the explanation above, it can be concluded that:

1. Simultaneously, technology literacy (X1) and technology integration (X2) significantly influence the teaching competencies by $32.8 \%$.

2. Partially, the effect of technology literacy $(X 1)$ on teaching competency $(Y)$ reached 9.18\% while the influence of technology integration $(X 2)$ on teaching competency (Y) was $12.75 \%$.

3. The role of technology integration is higher than the role of technology literacy in improving teaching competency. Students get technology integration facilities in the same composition, so the teaching competencies received by students from this technology integration tend to be the same in ceteris paribus, while teaching knowledge obtained from the knowledge of literacy technology tends to vary. Students who have higher technology literacy will take advantage of their ability to get more references so that their teaching competencies also increase. Thus, students are emphasized to have insight into technological literacy so that their teaching knowledge increases, not only limited to the knowledge gained from lecturers. The faculty must also provide more technology facilities to students and lecturers to enable them to pursue technological advancements. 


\section{References}

[1] Allen, R. (Fall 2001). Technology and learning: How schools map routes to technology's promised land. ASCD Curriculum Update, vol. 1-3, pp. 6-8.

[2] Ball, D. L., Thames, M. H., and Phelps, G. (2008). Content knowledge for teaching: What makes it special? Journal of Teacher Education, vol. 59, pp. 389-407

[3] Becker, H. J. (2001). How are teachers using computers in instruction? Paper presented at the 2001 meeting of the American Educational Research Association. Retrieved from: http://www.crito.uci.edu/tlc/FINDINGS/special3/ (accessed on May 25, 2005).

[4] Dawson, C. and Rakes, G. C. (2003). The influence of principals' technology training on the integration of technology into schools. Journal of Research on Technology in Education, vol. 36, no. 1, pp. 29-49

[5] Christensen, R. (2002). Effects of technology integration education on the attitudes of teachers and students. Journal of Research on Technology in Education, vol. 34, no. 4 , pp. $411-433$.

[6] Georgina, D. A. and Olson, M. R. (2008). Integration of technology in higher education: A review of faculty self-perceptions. Internet and Higher Education, vol. 11, pp. 1-8.

[7] Guzman, A. and Nussbaum, M. (2009). Teaching competencies for technology integration in the classroom. Journal of Computer Assisted Learning, vol. 25, pp. 453-469.

[8] Harususilo, Y. E. (2018). Menguatkan Kepemimpinan Generasi Milenial [Online]. Retrieved from: https://edukasi.kompas.com/read/2018/09/06/21432481/ menguatkan-kepemimpinan-generasi-milenial (accessed on September 7, 2018).

[9] Katz, I. R. and Macklin, A. S. Information and Communication Technology (ICT) literacy: Integration and assessment in higher education. Systemics, Cybernetics and Informatics, vol. 5, no. 4.

[10] Keengwe, J., Onchwari, G., and Wachira, P. (2008). Computer technology integration and student learning: Barriers and promise. Journal of Science Education and Technology, vol. 17, pp. 560-565.

[11] Keengwe, J. (2007). Faculty Integration of technology into instruction and students' perceptions of computer technology to improve student learning. Journal of Information Technology Education, vol. 6.

[12] Maryland State Department of Education. (2005). Maryland Technology Education State Curriculum [Online]. Retrieved from: marylandpublicschools.org 
[13] National Academy of Engineering and National Research Council of The National Academis. (2006). Tech Tally: Approaches to Assessing Technological Literacy [Online]. Retrieved from: http://download.nap.edu/cart/download.cgi?\&record_id= 11691\&free $=1$

[14] Oppenheimer, T. (2003). The Flickering Mind: The False Promise of Technology in the Classroom and How Learning Can Be Saved. New York: Random House.

[15] lannuzzi, P. (2000). Information literacy competency standards for higher education. Community \& Junior College Libraries, vol. 9, no. 4, pp. 63-67.

[16] Roblyer, M. D. and Knezek, G. A. (2003). New millennium research for educational technology: A call for a national research agenda. Journal of Research on Technology in Education, vol. 36, no. 1, pp. 60-71.

[17] Rockman, I. F. (2004). Integrating Information Literacy into the Higher Education Curriculum: Practical Models for Transformation. San Francisco, CA: Jossey-Bass.

[18] Rose, A. M. (2007). Perceptions of technological literacy among science, technology, engineering, and mathematics leaders. Journal of Technology Education, vol. 19, no. 1, Fall 2007 [Online]. Retrieved from: http:/www.google.co.id/url?sa= t\&rct=j\&q=\&esrc=s\&source=web\&cd=2\&cad=rja\&ved=0CEAQFjAB\&url=http\% 3A\%2F\%2Fscholar.lib.vt.edu\%2Fejournals\%2FJTE\%2Fv19n1\%2Fpdf\%2Frose. pdf\&ei=kZJFUeijMYKJrAfdp4CYCg\&usg=AFQjCNF5Ed02qWkPGc3tgj1Q9DgJcIVDQ\&sig2=2j94EeXtjaZDp2IXQTp7pg

[19] Schwab, K. (2015). The Fourth Industrial Revolution: What It Means and How to Respond. Retrieved from: https://www.foreignaffairs.com/articles/2015-12-12/fourthindustrial-revolution

[20] Schwab, K. (2017). The Fourth Industrial Revolution. Crown Business Press.

[21] Setyaningsih, L. (2018). Peningkatan Kompetensi Guru Merupakan Keharusan [Online]. Retrieved from: http://wartakota.tribunnews.com/2018/09/28/peningkatankompetensi-guru-merupakan-keharusan (accessed on September 7, 2018).

[22] Sprague, D., Kopfman, K., and Dorsey, S. de L. (1998). Faculty development in the integration of technology in teacher education courses. Journal of Computing in Teacher Education, vol. 14, no. 2, pp. 24-28.

[23] Strudler, N. (2003). Answering the call: A response to Roblyer and Knezek. Journal of Research on Technology in Education, vol. 36, no. 1, pp. 72-76.

[24] Tiananda, F. (2015). Kompetensi Pedagogik Guru Ditinjau dari Penguasaan Teknologi Informasi Komunikasi Dan Pengalaman Mengajar di SMK Muhammadiyah 2 Sragen Tahun Ajaran 2014/2015. Thesis, Fakultas Keguruan dan Ilmu Pendidikan, Universitas Muhammadiyah Surakarta. 
[25] Wijaya, M. (2012). Pengembangan Model Pembelajaran e-Learning Berbasis Web dengan Prinsip e-Pedagogy dalam Meningkatkan Hasil Belajar. Jurnal Pendidikan Penabur, vol. 11, pp. 20-37.

[26] Zhao, Y. and Bryant, F. L. Can teacher technology integration training alone lead to high levels of technology integration? A qualitative look at teachers' technology integration after state mandated technology training. Electronic Journal for the Integration of Technology in Education, vol. 5, pp. 53-62. 